\title{
The Existence of Modern Mini Markets amidst Traditional Retail Market
}

\author{
Andi Ayu Frihatni \\ Accounting, IAIN Parepare \\ Parepare, South Sulawesi, Indonesia. \\ * Corresponding author: \\ Email: andiayufrihatni@iainpare.ac.id
}

\begin{abstract}
.
This research aims at discussing the existence of modern mini market consisting amidst traditional retail market. I $t$ was conducted at Parepare, South Sulawesi, Indonesia. Modern mini market in this research consisted of the Alfamart, Indomaret, and Alfamidi. The data analysis used in this study used a quantitative approach. The data analysis techniques in this study use descriptive statistics and simple regression as well as paired t-test. The result of this research found that the existence of modern mini market has no effects on the going concern of traditional retail market.
\end{abstract}

Keywords: Consumer, Income, Modern Mini Market, Traditional Market

\section{INTRODUCTION}

According to the Indonesian Retail Entrepreneurs Association (APRINDO), retail business or retail business in Indonesia began to grow in the 1980s as the Indonesian economy began to develop [1]. This arises as a result of the growth in middle class communities, which leads to the rise of demand for supermarkets and convenience stores in urban areas. This trend is what is currently happening and is expected to be sustainable in the future. Another thing that drives the development of retail business in Indonesia is the changing lifestyle of upper middle class people, especially in urban areas that tend to prefer shopping in modern shopping centers. The change in shopping patterns that occur in urban communities is not only to meet the needs of shopping but also just to walk around and seek entertainment. The growth of business in the retail industry is also followed by increasingly intense competition between a number of local retailers and foreign retailers that are emerging in Indonesia [2].

The presence of convenience stores in Parepare city such as Alfamart, Indomaret, and Alfamidi has existed in various locations, even expanding to the suburbs, this is underlined by the lifestyle and shopping patterns of the people in Parepare City that are increasingly advanced. The development of this trade is certainly not separated from the economic growth of a region and also affects the economic 
development in the area. The small market certainly contributes to the receipt of tax and decreases the number of unemployements in Indonesia [3].

Table 1. Modern Mini Market at Parepare, South Sulawesi, Indonesia

\begin{tabular}{|clccc|}
\hline No. & District & Alfamart & Indomaret & Alfamidi \\
\hline 1. & Ujung & 3 & 4 & 1 \\
\hline 2. & Soreang & 7 & 2 & 2 \\
\hline 3. & Bacukiki & 1 & 1 & - \\
\hline 4. & Bacukiki Barat & 4 & 2 & 1 \\
\hline & Total & $\mathbf{1 5}$ & $\mathbf{9}$ & $\mathbf{4}$ \\
\hline
\end{tabular}

Table 2. Traditional Market at Parepare, South Sulawesi, Indonesia

\begin{tabular}{|clc|}
\hline No. & \multicolumn{1}{c|}{ District } & Total \\
\hline $\mathbf{1 .}$ & Ujung & 173 \\
\hline $\mathbf{2 .}$ & Soreang & 129 \\
\hline $\mathbf{3 .}$ & Bacukiki & 288 \\
\hline $\mathbf{4 .}$ & Bacukiki Barat & 167 \\
\hline & Total & $\mathbf{7 5 7}$ \\
\hline
\end{tabular}

From the development of modern retail, it can be seen that the business of stalls or small stalls began to be eliminated. The existence of modern shops makes small market lose a lot of their customers. The limitations that small markets have, it is not possible to be able to compete well with larger stores. The facilities and quality provided by large stores make consumers prefer to shop at such places including supermarkets, Alfamart, Indomaret, Alfamidi and similar convenience stores that are starting to develop. The rapid development of convenience stores in Parepare city and competitive prices, currently feared to have an impact on traditional market business revenue. In these circumstances, the stall owner must be able to survive and compete with modern minimarkets, in order for his business to keep going.

Demand is the amount of an item or service that is willing and able to be purchased at various possible prices over a certain period of time assuming other things remain the same (cateris paribus). Derivative demand is the demand for production factors that depend on the demand for goods or services produced by such factors or resources[4]. Demand theory is a theory that explains the characteristics of the relationship between the number of requests and the price. Based on the characteristic relationship between demand and price can be created a chart of the demand curve. [5], [6]. The distribution of people's income can affect the pattern of public demand for an item. The greater the amount of public income will give rise to different patterns of community demand. If the government imposes a high tax on luxury goods, then the proceeds of the tax, used to increase the incomes of low-income working people, there will be a decrease in demand for luxury goods and increased demand for goods needed by people whose incomes increase. Besides, market power theory has the role in the market competition. The marketability is a key of profitability[7]. It looks interesting when two same industries exist in the market. 
The purpose of this research is to find out the income conditions and profit levels of traditional market businesses located around Alfamart, Indomaret, and Alfamidi. In addition to knowing the change in the number of buyers and changes in the opening hours of traditional market business before and after the arrival of Alfamart, Indomaret, and Alfamidi.

\section{METHODS}

This type of research is quantitative. The number of samples to be examined is as many as 60 respondents according to the characteristics of the sample that has been determined. For the data collection required in this study, researchers used related questionnaires before and after the arrival of Alfamart, Indomaret, and Alfamidi in Parepare.

Table 3. Total Respondent

\begin{tabular}{|l|c|c|c|c|c|}
\hline Characteristic & Ujung & Soreang & Bacukiki & $\begin{array}{c}\text { Bacukiki } \\
\text { Barat }\end{array}$ & Total \\
\hline $\begin{array}{l}\text { Sell the same goods or } \\
\text { products and have a close } \\
\text { distance (100-200 m) with }\end{array}$ & 15 & 25 & 8 & 12 & 60 \\
$\begin{array}{l}\text { Alfamart, Indomaret, and } \\
\text { Alfamidi }\end{array}$ & & & & & \\
\hline
\end{tabular}

The common method of data collection used in a study is by observation, interview, and questionnaire. Research instruments used in data collection conducted by researchers are questionnaires (questionnaires) and interviews, to find out more about the influence of Alfamart, Indomaret, and Alfamidi on traditional market business income. The data analysis used in this study used a quantitative approach. The data analysis techniques in this study use statistics. As for the type of statistics used in this study there are two that are descriptive statistics and simple regression as well as paired T-Test.

\section{RESULT AND DISCUSSION}

The statistical analysis used in this study is to use multiple linear regression analyses. In linear regression analysis it is multiple to calculate the quantitative effect of an event change (variable X) on another event (variable Y). in this study, multiple regression analysis serves as a statistical technique used to test the influence of Alfamart, Indomaret, and Alfamidi presence factors on traditional market businesses in Parepare city.

Based on the table 4, the significant value is $0.000>0.05$ in the regression model. It indicates that the existence of modern mini market has no effect on the traditional retail market income. The existence of Alfamart, Indomaret, and Alfamidi has no effect on traditional maket income. From the results of the test, it can be concluded that the existence of Alfamart, Indomaret, and Alfamidi did not have a positive effect on the business revenue of the traditional market. This can mean that 
International Journal Of Science, Technology \& Management

although Alfamart, Indomaret and Alfamidi are growing rapidly it still does not affect the revenue of traditional market businesses

Table 4. The Result of Regression

\begin{tabular}{|c|c|c|c|c|c|}
\hline & \multicolumn{2}{|c|}{$\begin{array}{c}\text { Unstandarized } \\
\text { Coefficients }\end{array}$} & $\begin{array}{l}\text { Standarized } \\
\text { Coefficients }\end{array}$ & \multicolumn{2}{|c|}{} \\
\cline { 2 - 6 } & \multicolumn{1}{|c|}{ B } & Std. Error & Beta & T & Sig. \\
\hline \multicolumn{1}{|c|}{ (Constant) } & 79,887 & 4,328 & & 18,459 & 0,000 \\
\hline $\begin{array}{l}\text { Modern Mini Markets } \\
\text { ( Alfamart, Indomaret, } \\
\text { Alfamidi) }\end{array}$ & - & 0.098 & $-0,122$ & $-0,937$ & 0,353 \\
\hline
\end{tabular}

a. Dependent Variable : Traditional Retail Market Income

Table 5. Paired Sample T-Test

\begin{tabular}{|c|c|c|c|c|c|c|c|c|c|}
\hline \multicolumn{2}{|c|}{ Variabel } & Mean & $\begin{array}{c}\text { Std. } \\
\text { Deviation }\end{array}$ & $\begin{array}{c}\text { Std. Eror } \\
\text { Mean }\end{array}$ & Correlation & Sig. & $\mathbf{t}$ & Df & $\begin{array}{c}\text { Sig } \\
\text {. }\end{array}$ \\
\hline \multirow[t]{2}{*}{ Pair 1} & $\mathrm{X} .4$ & 2.77 & 0,621 & 0,080 & \multirow[b]{2}{*}{0,241} & \multirow[b]{2}{*}{0,064} & \multirow[b]{2}{*}{$-12,503$} & \multirow[b]{2}{*}{59} & \multirow[b]{2}{*}{0,000} \\
\hline & X.5 & 3.87 & 0,468 & 0,060 & & & & & \\
\hline \multirow[t]{2}{*}{ Pair 2} & X.6 & 2.65 & 0,659 & 0,085 & \multirow[b]{2}{*}{0,151} & \multirow[b]{2}{*}{0,251} & \multirow[b]{2}{*}{$-7,775$} & \multirow[b]{2}{*}{59} & \multirow[b]{2}{*}{0,000} \\
\hline & X.7 & 3.60 & 0,785 & 0,101 & & & & & \\
\hline \multirow[t]{2}{*}{ Pair 3} & X.8 & 2.03 & 0,610 & 0,079 & \multirow[b]{2}{*}{0,311} & \multirow[b]{2}{*}{0,015} & \multirow[b]{2}{*}{$-14,605$} & \multirow[b]{2}{*}{59} & \multirow[b]{2}{*}{0,000} \\
\hline & X.9 & 3.60 & 0,785 & 0,101 & & & & & \\
\hline \multirow[t]{2}{*}{ Pair 4} & X.14 & 2.22 & 0,585 & 0,076 & \multirow[b]{2}{*}{0,155} & \multirow[b]{2}{*}{0,237} & \multirow[b]{2}{*}{$-11,857$} & \multirow[b]{2}{*}{59} & \multirow[b]{2}{*}{0,000} \\
\hline & X.15 & 3.60 & 0,785 & 0,101 & & & & & \\
\hline
\end{tabular}

If the significant value in paired sample t-test is more than 0.05 , it would indicates that the variables has significant difference. Based on table 5, it shows the value of 0.000 , it indicates no different effects. In this case, the existence of Alfamart, Indomaret, and Alfamidi has no effect on the profits of traditional market businesses (Pair 1). This can mean that although Alfamart, Indomaret and Alfamidi are growing rapidly it still does not affect the profits of raditional market businesses. In addition, the cause of the in effect of alfamart, Indomaret, and Alfamidi's existence on the profit of traditional market business, caused by the average traditional market business around the convenience store location, is the business of stalls that were newly established or established after the existence of a convenience store in the location. Besides, the existence of Alfamart, Indomaret, and Alfamidi has no effect on the number of traditional market business consumers (pair 2). From the results of the test, it can be concluded that the existence of Alfamart, Indomaret, and Alfamidi has no effect on the number of traditional market business consumers. This can be interpreted that although Alfamart, Indomaret and Alfamidi are growing rapidly it still does not affect the number of consumers of traditional market businesses. In addition, the cause of the in effect of the existence of Alfamart, Indomaret, and Alfamidi to the number of traditional market business consumers, is because the traditional market business has different groups or consumers to consumers Alfamart, Indomaret, and Alfamidi.

At the test of pair 4 (X.14 and X.15), it can be concluded that the existence of Alfamart, Indomaret, and Alfamidi with 24-hour opening hours has no effect on the 
opening hours / close of retail businesses. From the results of the test, the existence of Alfamart, Indomaret, and Alfamidi had no positive effect on the opening hours / close of traditional market businesses. This can be interpreted that even though Alfamart, Indomaret and Alfamidi growing rapidly still does not affect the opening hours / close of traditional market businesses.

Overall, traditional market businesses located around Alfamart, Indomaret, and Alfamidi did not experience a significant influence on revenue, profits, number of consumers, and opening/closing hours. It is in line with previous study [1]. Related to the in effect of the existence of Alfamart, Indomaret, and Alfamidi on the traditional market business there are several factors that are the cause including,

1) The existence of traditional market businesses are generally newly established around alfamart, Indomaret, and Alfamidi locations. So the stall business owner did not feel the impact of the existence of the convenience store.

2) traditional market businesses generally have different consumers than those who shop in Alfamart, Indomaret, and Alfamidi. The average consumer who shops at a convenience store is among consumers with income or income that is middle to upper.

3) The need to shop fast is also a factor in the in effect of the existence of Alfamart, Indomaret, and Alfamidi to the traditional market business. The average consumer who shops at a traditional market business, is a consumer who only buys one or two items, so that requires practicality and speed of shopping. Unlike when shopping at convenience stores, which consumers generally do to buy large quantities of goods.

The price of goods sold in Alfamart, Indomaret, and Alfamidi is generally more expensive than the price of goods sold at business traditional markets. Thus, the average consumer prefers to shop at traditional retail businesses.

Based on these factors, although the development of Alfamart, Indo maret, and Alfamidi are quite rapid in Parepare City, it does not really affect the income, profits, number of consumers, and the opening hours / close of traditional retail businesses. If seen from previous research that the existence of Alfamart, Indomaret, and Alfamidi has a significant effect on the income and development of traditional market businesses due to the average or majority of retail businesses in the previously researched area has stood long before the existence of Alfamart, Indomaret, and Alfamidi around the business[8][9][10]. Therefore, the retail business is affected by the existence of the convenience store. Changes in people's lifestyles in the area in previous research have also contributed strongly to the changing tastes of the shopping community.

Reviewing the interconnectedness of the theory used as the basis of this research, it can be analyzed that although people's tastes have changed in terms of the selection of shopping places that affect the demand and supply of modern convenience stores, the existence of traditional market businesses still remains in the city of Parepare as a practical shopping place. People's tastes are one of the few factors that play an important role in demand and supply theory. While if in the analysis of the relationship of marketing theory with the results of the research, it can be analyzed that 
the traditional market business turns out to have its own marketing techniques in terms of facing business competition with Alfamart, Indomaret, and Alfamidi. Marketing techniques commonly applied by traditional market businesses include providing delivery services for products such as gas and mineral water in the form of gallons. Furthermore, to maintain its existence the traditional market business also performs marketing techniques by adding business or type of products that it sells to be more varied so as to attract consumers to keep shopping at the traditional market business.

So it can be concluded that the existence of two types of eritel in Parepare City can still go hand in hand, without having to cause conflict between the two retailers as happened in some areas in previous research.

\section{CONCLUSION}

Based on the analysis of the above research results, it can be drawn several conclusions as follows. First, the existence of Alfamart, Indomaret, and Alfamidi has no positive effect on traditional market business income. This can mean that although Alfamart, Indomaret and Alfamidi are growing rapidly it still does not affect the revenue of traditional market businesses. Second, the existence of Alfamart, Indomaret, and Alfamidi has no positive effect on the profits of traditional market businesses. This can mean that although Alfamart, Indomaret and Alfamidi are growing rapidly it still does not affect the profits of traditional market businesses. In addition, the cause of the in effect of alfamart, Indomaret, and Alfamidi's existence on the profit of traditional market business, caused by the average traditional market business around the convenience store location, is the business of stalls that were newly established or established after the existence of a convenience store in the location. Third, the existence of Alfamart, Indomaret, and Alfamidi has no positive effect on the reduction in the number of consumers. This can be interpreted that although Alfamart, Indomaret and Alfamidi are growing rapidly it still does not affect the number of consumers of traditional market businesses. In addition, the cause of the in effect of the existence of Alfamart, Indomaret, and Alfamidi to the number of traditional market business consumers, is because the traditional market business has different groups or consumers to consumers Alfamart, Indomaret, and Alfamidi. Fourth, the existence of Alfamart, Indomaret, and Alfamidi has no effect on changes in the opening hours / close of traditional market businesses. Furthermore, this research has urgent limitations such as sample size with limited respondents. This case can be a suggestion for future study.

\section{REFERENCES}

[1] S. Sulmiah, "Perkembangan Pasar Modern di Indonesia dan Dampaknya terhadap Pasar Tradisional," Latihan, 2017.

[2] E. Soliha, "Analisis Industri Ritel di Indonesia,” J. Bisnis dan Ekon., 2008.

[3] W. O. Rayyani, A. Arizah, and A. Abbas, "The Coaching Assistance of Preparing of Financial Statements based on SAK EMKM Integrated [Asistensi Pembinaan Penyusunan Laporan Keuangan Berbasis SAK EMKM yang Terintegrasi]," Proceeding Community Dev., 2019, doi: 10.30874/comdev.2018.193.

[4] G. Lorenzoni, "A theory of demand shocks," Am. Econ. Rev., 2009, doi: 10.1257/aer.99.5.2050.

[5] A. Smith, “Teori Ekonomi Mikro 1," pasar bebas, 2011. 
[6] A. Sudarman, "Teori Ekonomi Mikro 1," Pasar Bebas, 2011.

[7] A. Abbas and A. Arizah, "Marketability, profitability, and profit-loss sharing: evidence from sharia banking in Indonesia," Asian J. Account. Res., 2019, doi: 10.1108/ajar-082019-0065.

[8] E. Sarwoko, "Dampak Modernisasi Keberadaan Pasar Modern terhadap Pedagang Pasar Tradisional di Wilayah Kabupaten Malang," J. Ekon. Mod., 2008, doi: 10.21067/jem.v4i2.880.

[9] N. Arianty, "Analisis Perbedaan Pasar Modern Dan Pasar Tradisional Ditinjau Dari Strategi Tata Letak (Lay Out) Dan Kualitas Pelayanan Untuk Meningkatkan Posisi Tawar Pasar Tradisional," J. Manaj. Bisnis, 2013.

[10] D. Aryani, "Efek Pendapatan Pedagang Tradisional Dari Ramainya Kemunculan Minimarket di Kota Malang,” J. Din. Manaj., 2011, doi: 10.15294/jdm.v2i2.2481. 